\title{
Integrated, Decentralized Wastewater Management for Resource Recovery in Rural and Peri-Urban Areas
}

\author{
Andrea G. Capodaglio \\ Department of Civil Engineering \& Architecture, University of Pavia, 27100 Pavia, Italy; capo@unipv.it \\ Academic Editor: Antonio A. R. Ioris \\ Received: 21 April 2017; Accepted: 12 June 2017; Published: 15 June 2017
}

\begin{abstract}
Collection and treatment of wastewater have a huge impact on the environment and economy, both at the local and global levels. Eco-innovation may play a paramount role in the reduction of the environmental impact of such systems, and in their greater sustainability in economic, environmental, and social terms. Decentralization appears as a logical solution to tackle sustainability problems of wastewater management systems, as it focuses on the on-site treatment of wastewater and on local recycling and reuse of resources contained in domestic wastewater (in primus, water itself). This paper analyses the needs, technological options and contribution to water management of decentralized systems. Decentralized solutions in general will tend to be compatible with local water use and reuse requirements, where locally treated water could support agricultural productivity or (in more urban areas) be used as a substitute for drinking-quality supply water for compatible uses. In analyzing sustainability of technology, different dimensions should be taken into account (in particular, local issues). There is no fixed or universal solution to the technological issue; to the contrary, all relevant studies demonstrated there are varying degrees of sustainability in the way a technology is selected and operated, to avoid exporting problems over time or space.
\end{abstract}

Keywords: wastewater management; resource recovery; recycle; sewerage collection; wastewater treatment; source separation

\section{Introduction}

Notwithstanding the ongoing worldwide urbanization phenomenon, about half of the world population still lives in rural areas. In the EU, about $30 \%$ of the population of former CEE (Central and Easter European) countries (42 million people) lives in settlements of less than 2000, while this percentage is lower than $20 \%$ in the western part [1]. Many other areas of the world show a still preponderantly rural or peri-urban (settlements in proximity of a large urban areas, but without the services and facilities proper of such areas) character. A large part of this population is still waiting for proper sanitation systems, or is aiming to improve the efficiency of existing ones and scale-up environmental protection and resources recovery. Goal 6 of the United Nations Sustainable Development Goals ("Clean Water and Sanitation") foresees achieving access to adequate and equitable sanitation and hygiene for all by 2030 and, within the same time frame, halving the proportion of untreated wastewater and substantially increasing recycling and safe reuse globally. Still, at the moment, at least 1.8 billion people globally use sources of drinking water that are fecally contaminated, over 1.7 billion people currently live in river basins where water use exceeds recharge, and more than $80 \%$ of wastewater from human activities is discharged without any pollution removal [2].

Collection and treatment of wastewater have a huge impact on the environment and economy, both at the local and global levels. Risch et al. [3] conducted a life cycle assessment (LCA) of conventional (gravity) urban wastewater systems (UWS) based on a detailed components inventory, including construction and operation of both sewers and wastewater treatment plants (WWTPs). 
Results showed that the construction of sewer infrastructures themselves has, alone, an environmental impact on many of the considered categories that is larger than both the construction and operation of the WWTP. Hence, the importance of including the construction and operation of sewer systems in the environmental assessment of centralized versus decentralized options for UWSs.

In this context, eco-innovation may play a paramount role in the reduction of the environmental impact of such systems, and in their greater sustainability in economic, environmental and social terms. Arguments in favor of decentralized wastewater management systems for communities in rural or peri-urban areas have been discussed and advocated by many [4-9]. In addition to the fact that in remote (and especially low-income) settings centralized treatment would result in unsustainable long-term debt burdens for the population, decentralization appears as a logical solution to tackle sustainability problems, as these facilities can usually be built to exactly fulfil current needs (and be expanded later, as further needs arise). Even in developed countries, cities are gradually losing their character of densely concentrated settlements, and are gradually sprawling to the countryside. Therefore, in areas where construction of a centralized sewage collection system is not considered economically viable, decentralization is becoming quite popular: as an example, $25 \%$ of the population in the US was already served by small, decentralized WWTPs over a decade ago [10].

Since most of the developed world's existing urban water infrastructure was revamped substantially after World War II, it is therefore close to or past its useful design lifespan (usually considered to be 50-60 years), and due to undergo a new, substantial rehabilitation/refurbishment cycle within the next decade. Also, switching to smaller, local clusters-based systems in such settings could not only be a sensible solution sustainability-wise, but, in the long term, a financially sound one, as well [11].

\section{Decentralized Wastewater Management}

Decentralized wastewater management is used to treat and dispose, at or near the source, relatively small volumes of wastewater, originating from single households or groups of dwellings located in relatively close proximity (indicatively, less than 3-5 km, maximum) and not served by a central sewer system connecting them to a regional wastewater treatment plant (WWTP). This obviously still needs a local collection system, yet this will likely be much smaller and less expensive than those used for conventional, centralized treatment, especially when the greywater components have been separated from the black flow (as discussed in a later section [4,12]). The term decentralized also qualifies systems serving small portions (clusters) of an urban area according to hydrology, landscape, and local ecology considerations. Sustainable decentralized sanitation focuses on the on-site treatment of wastewater and local recycling and reuse of resources contained in domestic wastewater (in primis, water itself). It has been claimed that decentralized treatment systems favor water recycling and reuse in proximity of their location [13]. Other resources that can be readily recycled are: bio-energy (mostly from organic material transformation, even though attempts are being made to recover water-embedded residual heat), and nutrients (mainly nitrogen and phosphorus) [14]. Also, in these cases local reuse of recovered components helps to form "closed loops" of resources uses, in line with the principles of "circular economy". To reduce use and wastage of resources, typical of a "once-through" resource use, the "closed loop" concept was introduced, whereby system resources, energy, and materials are re-used multiple times (even if for different purposes) with minimum processing required by each subsequent use. The "circular economy" is a new global economic paradigm that, looking beyond the current "take, make, and dispose" mode, is designed to be restorative and regenerative and, relying on system-wide innovation, aims to redefine products and services to eliminate waste, while minimizing negative impacts. The "closed loop" can therefore be viewed as a local version of circular economy (for details, refer to www.ellenmacarthurfoundation.org/circular-economy and local resources valorization). Although "conventional" technologies may as well be applied (at a reduced scale), to decentralized systems too, real advantages from such an approach in terms of energy savings (or even recovery) achievement of 
resources recovery and recycling, and functional process integration, will derive from the adoption of new, more sustainable process technologies, as will be illustrated henceforth.

It should be remembered that the two main historical objectives of wastewater management systems are: to protect and promote human health (by providing a clean environment and breaking the cycle of disease), and to provide water quality and ecosystems protection (by avoiding negative effects of excessive pollutants discharge into the environment [15]). The "most appropriate technology" in any situation is the one that turns out to be economically affordable, environmentally protective, technically and institutionally consistent, and socially acceptable for the specific application-in other words, one that is sustainable, according to all viewpoints. As an additional bouns, decentralized systems are generally compact, with highly flexible operating conditions and reduced aesthetic impact; however, other local impacts (i.e., odors, traffic) should be considered [16,17].

Table 1 summarizes the requirements for these systems; even though some may appear obvious, projects have failed due to planners' lack of consideration. As an example, Beijing (China), a city that is suffering from a severe water deficit ( 3.6 billion $\mathrm{m}^{3} / \mathrm{y}$ water consumption, far in excess of the 2.1 billion $\mathrm{m}^{3} / \mathrm{y}$ locally available) $[18,19]$ recently passed a building code requiring large buildings to internally recycle greywater for toilet flushing. The provision, however, is still largely unattended as residents find this use objectionable and uneconomical (in fact, it costs less to buy water from the public network than to operate the treatment units already installed for reuse), save for a few university buildings where this policy's acceptance was obtained from mostly young student residents [20]. It is clear from the Table below that different requirements were unaccounted for in this case: social acceptance, financial, and planning (technological).

Table 1. Decentralized wastewater management systems basic requirements.

\begin{tabular}{|c|c|c|}
\hline Issue/Impact & Requirements & Notes \\
\hline $\begin{array}{c}\text { Health and } \\
\text { Hygiene }\end{array}$ & $\begin{array}{l}\text { Minimize human risk of exposure to pathogens } \\
\text { and hazardous substances that could affect } \\
\text { public health, from the point of disposal to the } \\
\text { point of final discharge/reuse. }\end{array}$ & $\begin{array}{l}\text { Some degree of disinfection should be } \\
\text { provided in case of reuse or } \\
\text { human contact. }\end{array}$ \\
\hline $\begin{array}{l}\text { Environment and } \\
\text { Natural Resources }\end{array}$ & $\begin{array}{l}\text { In addition to pollutant removal effectiveness, } \\
\text { resources for system construction and operation, } \\
\text { as well as resulting emissions, must be } \\
\text { considered. Degree of recycling and re-use from } \\
\text { operation (e.g., returning water, nutrients, and } \\
\text { organic material to agriculture), and protection of } \\
\text { non-renewable resources (e.g., production of } \\
\text { biogas) must be also compounded. }\end{array}$ & $\begin{array}{l}\text { Receiving environment is crucial for } \\
\text { technology selection. Site evaluation } \\
\text { processes and assessment of its carrying } \\
\text { capacity should be carried out. }\end{array}$ \\
\hline Technology & $\begin{array}{l}\text { Functionality maximization, ease of construction, } \\
\text { operation, and monitoring by local utilities are } \\
\text { paramount in case of decentralized systems. }\end{array}$ & $\begin{array}{l}\text { Robustness and/or vulnerability } \\
\text { towards power cuts, water shortages, } \\
\text { floods, etc., are important. }\end{array}$ \\
\hline $\begin{array}{c}\text { Financial and } \\
\text { Economic }\end{array}$ & $\begin{array}{l}\text { Decentralized systems must relate to the capacity } \\
\text { of local households / communities to pay for the } \\
\text { system (including construction, operation, } \\
\text { maintenance, and necessary reinvestments). }\end{array}$ & $\begin{array}{l}\text { Systems should provide service without } \\
\text { becoming excessive financial burdens } \\
\text { on the users' community. }\end{array}$ \\
\hline $\begin{array}{l}\text { Socio-Cultural and } \\
\text { Institutional }\end{array}$ & $\begin{array}{l}\text { Socio-cultural acceptance, convenience, } \\
\text { perception, impact on human dignity, compliance } \\
\text { with the legal framework, and institutional } \\
\text { settings must be considered. }\end{array}$ & $\begin{array}{l}\text { Users must be informed and accept } \\
\text { underlying practices, including those of } \\
\text { reuse and recycle of resources. }\end{array}$ \\
\hline $\begin{array}{c}\text { Aesthetics and } \\
\text { Nuisance }\end{array}$ & $\begin{array}{l}\text { Aesthetic impact should be reduced, as } \\
\text { decentralized systems are usually closer to } \\
\text { residential areas. Nature integration and } \\
\text { ecological function or (on the other hand) } \\
\text { mimetism or concealment should be included in } \\
\text { design. Design and operation must take into } \\
\text { account possible nuisance factors (i.e., odors) and } \\
\text { prevent them. }\end{array}$ & $\begin{array}{l}\text { Public is especially sensitive to highly } \\
\text { subjective nuisance factors (odors rank } \\
\text { highly among them). Good practices } \\
\text { can reduce rejection risk. }\end{array}$ \\
\hline
\end{tabular}


Generally speaking, decentralized systems require more awareness, involvement, and participation from local users than centralized ones. The decision to implement a decentralized solution to wastewater treatment needs is usually made or discussed at the local level, and local stakeholders are usually more proactive when considering these systems [21]. They may be very well accepted when their objectives and advantages (including economical ones) have been clearly illustrated to users, as frequently happens with other environment-related projects [22]. In a few EU countries (Germany, The Netherlands) demonstrative decentralized systems serving up to 1000 people have been implemented in urban areas (examples: Knittlingen and Jenfelder Au, Sneek), incorporating reuse of water, energy, and resources, and receiving vast support by residents $[23,24]$.

A recent study by Suriyachan et al. [25] examined three cases in the city of Bangkok, using case study research methods to evaluate the potential of centralized and decentralized wastewater management approaches for urban development. The results showed that decentralized management proved economically and technically efficient, and conductive to sustainable urban development in the application area. Decentralization showed a competitive cost structure (as result of shorter sewer lines), simpler technology, and limited additional costs, while high efficiency could be achieved with good operation and maintenance $(\mathrm{O} \& \mathrm{M})$. Locally reclaimed water was largely (30-100\%) used for landscape irrigation of green areas, while in centralized systems less than $5 \%$ of the effluent was recycled. In addition to the financial aspect, sustainability of such systems was shown to lie in the social value of the public amenities they provide, and in the implication that they could be an additional driver for smart growth. No conflicts were observed in the study with sustainable urban development, even in the innermost, more densely populated urban areas.

In traditional systems, household discharge streams are combined and transported by an extended sewer system to a (possibly) far away, centralized WWTP. Collection and treatment of wastewater with a centralized approach often requires more pumps, longer and bigger pipes, and more energy than decentralized ones, increasing the infrastructure cost of the system [26]. About $80-90 \%$ of capital costs in such systems can be related to the collection system itself, with some possible economy of scale in the most densely populated areas [27]. An argument often brought up by supporters of centralized systems is that wastewater treatment cost per unit volume in such systems is more competitive (due to economies-of-scale) compared to decentralization. This is partly true-where a wastewater collection system already exists; however, it is estimated that any collection system (as a whole or parts of it) needs to be more or less completely renewed every 50-70 years, besides the required continuing maintenance [27]. Also, in case of new/refurbished systems, it is often found that the initial flow received is much less (50-80\%) than the design flow (calculated for a planning horizon of 30 or more years) for a considerable amount of time. This means that, save for some countries with extremely fast urbanization rates (e.g., India, Middle East), a centralized system could have substantial idle capacity that remains such until demand grows into it, paying money in advance for future scenarios that may not develop and potentially stopping more urgent investments elsewhere [28]. Decentralized systems, on the contrary, use a more cost-effective 'pay-as-you-go' (or 'just-in-time') approach in which capacity can be added incrementally and quickly [29]. In case of large block redevelopment in metropolitan areas with centralized sewage collection systems, a paradigmatic switch may therefore be worthy of consideration.

The following sections will analyze wastewater treatment and collection/conveyance technologies, respectively, with special consideration of their applicability in decentralized systems and technological, ecological, and economical sustainability.

\section{Sustainable Design of New Decentralized Wastewater Treatment Systems}

Applicable decentralized systems technologies encompass a wide range of processes of varying sophistication and complexity. Even from the cost viewpoint, more advanced technological options are rapidly becoming comparable-per unit of treated pollutant load—-to centralized applications [30]. Decentralized facilities can nowadays be easily controlled at a distance, facilitating $\mathrm{O}$ \& $\mathrm{M}$ aspects; 
in the past, the lack of reliable remote monitoring technology constituted a serious obstacle to decentralization, often resulting in unsustainable personnel requirements and/or unreliable treatment results. Recent common availability of robust remote sensor technology dramatically reduced onsite monitoring requirements, allowing telemetric control of distant facilities and demand-actuated on-site maintenance [31].

A commonly used on-site, simple system to treat wastewater has traditionally been a septic tank, followed often by soil disposal. The processes occurring in septic tanks (settling, anaerobic conversion of organic matter, and accumulation of inert particles with loose contact between sludge and wastewater) result in low conversion of organic components. Sludge accumulation at the bottom, and accumulation of floating oil and fats in a surface scum layer, gradually reduces the net available volume, and hence wastes retention time. Consequently, sludge and scum need to be removed periodically, before the efficiency of settling deteriorates and particles are washed out of the reactor. It is estimated that up to $50 \%$ of the organic matter may actually decompose in a septic tank, depending on operating temperature and retention. While septic systems allow partial, local water reuse with important limitations, they do not offer much in terms of resources and energy recovery. Although limited by poor efficiency, septic and "Imhoff" tanks (and many other similar design variations) are still vastly used in low income and remote areas, especially for isolated dwellings. In addition to these, and to small, activated sludge-based plants, several other process technologies are being preferentially developed (among all the available ones) for use in decentralized systems $[8,32]$.

\subsection{Constructed Wetlands}

Constructed wetlands (CWs) are currently being proposed throughout the world as decentralized systems (as an alternative to traditional ones), with a diversity of design and operational features that can be adapted to treat domestic, agricultural and industrial (mostly agro-food) wastewaters. Use of CWs for small to medium size settlements has increased sharply in Mediterranean countries due to favorable climatic conditions, and positive experiences have been reported even in northern EU countries, such as Poland, Estonia, and Lithuania [33]. CWs have several inherent advantages compared to traditional systems, including very low capital costs, less infrastructure, lower operating costs, simplicity of design, and ease of operation [34]. Excess plant biomass has to be removed regularly to prevent secondary pollution. Unit area (U.A.) land requirements may be the critical issue with this class of processes, ranging from about $2 \mathrm{~m}^{2} /$ P.E. (population equivalent) in warm countries to $12 \mathrm{~m}^{2} /$ P.E. in cold ones. A large footprint in colder regions, and water evaporation in hot, arid climates are the main drawbacks of these systems. Nutrient removal may occur both by biological and physico-chemical processes, but is strongly dependent on seasonality [35]. Wastewater disinfection may be provided separately by tertiary, solar-based stages. CWs facilities could also take direct advantage of their primary production by cultivating algae for single-cell protein production, or fish culture.

\subsection{Membrane Biological Reactors (and Related Technologies)}

One of the most promising technologies (capable of fulfilling current wastewater treatment requirements in traditional facilities) is represented by biologic membrane filtration processes, usually called Membrane Bio-Reactors (MBRs). MBR technology integrates biological degradation of wastewater pollutants with membrane filtration, ensuring effective removal of organic and inorganic contaminants and biological material from domestic and/or industrial wastewaters, and has become a proven alternative to traditional activated sludge systems due to low footprint requirements and high efficiency [36]. The filtration component dispenses the need for gravity clarification of the effluent, which could constitute a critical treatment bottleneck in small biological systems under highly varying hydraulic loads, even inducing process failure [37]. In addition to this, MBRs achieve, by efficiently withholding biomass in the reactor, high concentrations of active biomass, thus raising SRT within the system and providing better removal of slowly biodegradable compounds. Excess 
sludge production is also greatly reduced. Use of membrane systems in decentralized treatment of household (domestic) wastewater was described by several researchers [38,39]. When properly operated, MBRs have also shown the capability to effectively remove nutrients $[40,41]$ and - to some degree-micropollutants [42]. Depending on the pore size of the adopted membrane, MBRs may effectively remove pathogens, directly meeting water recycling standards without further disinfection. Limitations inherent to these processes are the installation costs (the membranes themselves plus the physical facility), high maintenance and energy requirements, and the progressive loss of filtration capacity due to medium fouling in time [36].

Quite similar technologies, consisting of biological reactors with suitable filters for biomass separation (BCR-Biomass Concentrator Reactor) have been proposed [6], after successful tests with poorly-treatable organic contaminants $[43,44]$. Treated effluent is filtered by a membrane-like medium for solids separation purposes, although with larger pore size $(>10-20 \mu \mathrm{m})$. Due to the coarser characteristics of the filter, effluent filtration occurs by gravity only with a minimal head loss and much lower fouling propensity. Both MBRs and BCRs operation can be modified to achieve nitrogen removal with comparable (75-79\%) removal efficiencies [45]. While these systems provide a very high effluent quality, post-treatment disinfection could still be needed for reuses with stringent quality requirements.

\subsection{Anaerobic Digestion Systems}

Today, anaerobic digestion is routinely used to process residual biological sludge from centralized WWTPs, allowing energy recovery in the form of biogas [46,47]; however, more modern forms of anaerobic digestion are currently considered an attractive, sustainable, and suitable technology for on-site wastewater treatment with energy recovery [48]. Due to their low energy consumption, relatively small space requirements, and simple reactor design, UASB (up-flow anaerobic sludge blanket) systems are used worldwide for treatment of various types of wastewater. This process, proposed in the 1980' by Lettinga and his group [49], combines good removal efficiency of organic matter due to the formation of a dense sludge blanket (an accumulation of inert suspended solids from the influent, and biomass produced within) at the bottom of the reactor, in which up-flow velocity creates the conditions for enhanced bacterial aggregation and retention of active anaerobic sludge. Due to their operating principles, UASB reactors enable long sludge retention times (SRT) at relatively short hydraulic retention times (HRT). As no oxygen is needed, the high energetic cost of aeration is avoided, and sludge handling costs are also dramatically lower (as its production is 3-20 times lower than in aerobic systems). Although efficiency and effectiveness of anaerobic processes are enhanced by concentrated substrate and higher operating temperatures (better suited to take advantage of the lower process kinetics characteristic of anaerobes), these processes are actually applicable to many types of wastewater and environmental conditions, even to diluted wastewater at low process temperatures. Seghezzo et al. [50] reviewed the application of UASB rectors to sewerage in different environmental conditions in different countries. Reductions of total Chemical Oxygen Demand (COD) up to $80-90 \%$ were reported, and even at lower temperatures (above $20^{\circ} \mathrm{C}$ ) average removals around $70 \%$ could be expected.

A study by de Graaff et al. [51] showed that applying UASB treatment to concentrated black water from an experimental vacuum toilet system at ambient temperature, with total influent COD as high as $9800 \mathrm{mg} / \mathrm{L}$ and stable COD removal efficiencies of over $80 \%$, could be obtained, with methane generation as high as $1.8 \mathrm{~m}^{3} \mathrm{CH}_{4} / \mathrm{m}^{3}$ treated black water. Ideally, source separation and concentration of organic load could make UASB-type treatment more attractive, due to the low reactor volumes needed and high energetic recoveries.

\subsection{Sustainability of Wastewater Treatment Technologies}

Sustainability, as a concept, aims at maintaining economic wellbeing, protection of the environment, prudent use of natural resources, and equitable social progress [52]. It also involves the need to design systems assuring that the use of natural resources would not lead to diminished quality 
of life in the future. Therefore, the question is: How does that concept translate in the selection of a specific wastewater treatment technology, and which are the specific aspects of a technology that make it more balanced than others in sustainability terms? In general, sustainability of man-made systems (including wastewater treatment systems) could be evaluated through assessment tools such as exergy analysis, economic analysis, and life cycle assessment (LCA), or through the definition of an ad hoc set of suitable indicators. Table 2 summarizes some issues influencing the sustainability evaluation of the technologies illustrated in the previous sections. Selection of a specific technology, however, should not be based solely on technical considerations, but should also integrate human and environmental activities that rotate around the site. A choice of indicators should depend on the geographic and demographic characteristics of the involved community, taking into account social attributes such as workforce education level, and employment and topologic ones, such as space. High labor costs may prohibit the employment of additional workers, while low education and training may rule out technologies with high-skill labor requirements, and small available areas may affect projects located in high-density population regions. Indicators developed for one case may not be applicable to another, for example, due to wide geographical diversity of urban, rural and peri-urban areas, or simply because of the lack of consensus among peers about the specific local definition of sustainability.

Muga and Mihelcic [53] applied a comparative sustainability analysis of mechanical, lagoon, and land treatment technologies for wastewater treatment on case studies intended for communities with wastewater flow smaller than $20,000 \mathrm{~m}^{3} /$ day, using a set of sustainability indicators that had been specifically developed. Results showed that overall sustainability of wastewater treatment technology is a function of economic, environmental, and social dimensions, and the selection and interpretation of indicators is influenced by the area's geographic and demographic situation. While it is difficult to identify a "best overall option", the study demonstrated there are varying degrees of sustainability in the way a technology is selected and operated. Figure 1 shows the main issue categories that should be considered in evaluating technological sustainability of wastewater treatment technologies (and the interrelations between individual subcategories), illustrating the complexity of the evaluation process.

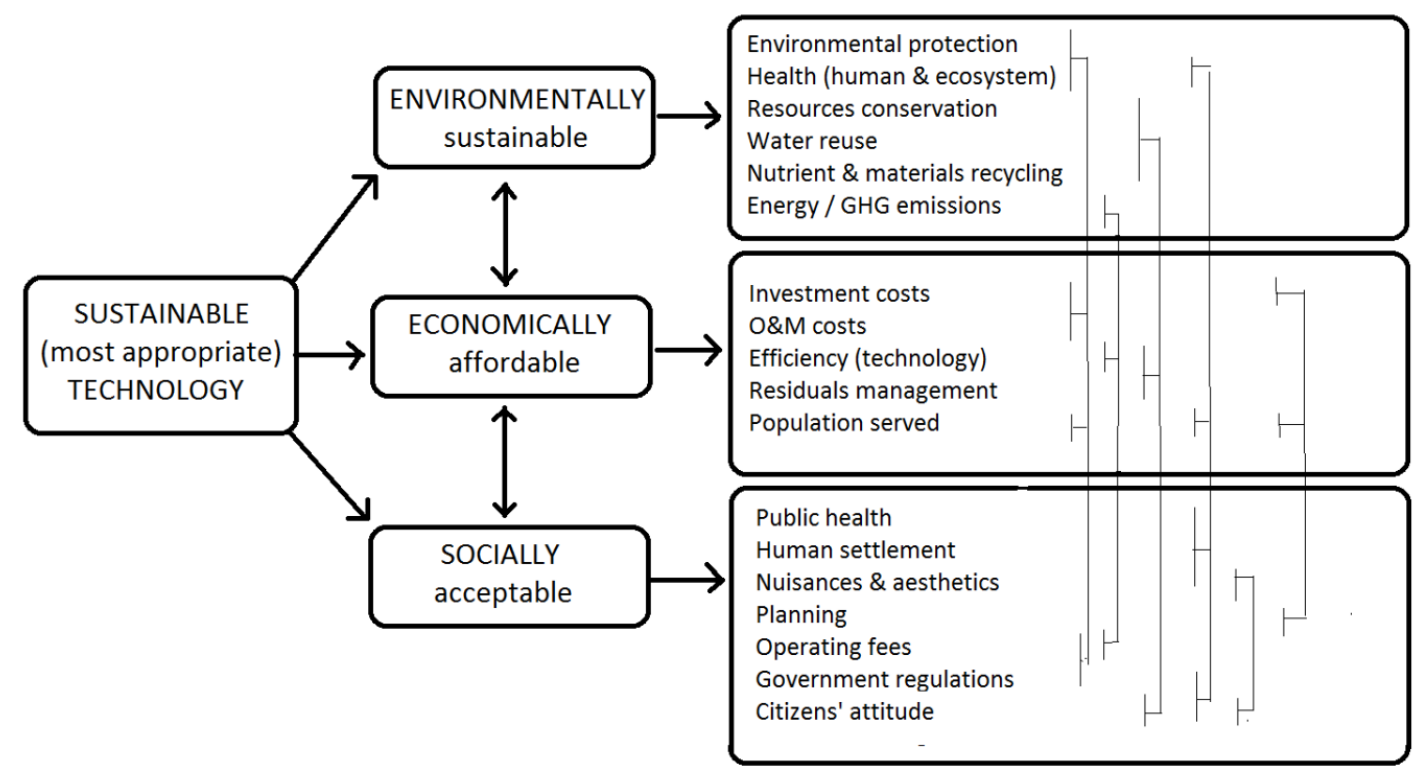

Figure 1. Issues categories, subcategories, and their relationships, which need addressing in a sustainability evaluation. 
Table 2. Sustainability-influencing factors for different wastewater treatment technologies.

\begin{tabular}{|c|c|c|c|c|}
\hline Issue Category & Septic Tanks (Imhoff \& Other) & Constructed Wetlands & MBRs & Anaerobic Processes (UASBs) \\
\hline \multicolumn{5}{|c|}{ Environment } \\
\hline $\begin{array}{l}\text { Environmental } \\
\text { protection }\end{array}$ & $\begin{array}{l}\text { Removal of settleable organic matter. } \\
\text { Partial removal of dissolved organic } \\
\text { matter, practically no } \\
\text { nutrients removal. }\end{array}$ & $\begin{array}{l}\text { Effective in removing organic } \\
\text { matter and, to a lesser } \\
\text { degree, nutrients. }\end{array}$ & $\begin{array}{l}\text { Quite effective in removing organic } \\
\text { matter; also effective in removing } \\
\text { some types of micropollutants and, } \\
\text { upon proper setup, nutrients. }\end{array}$ & $\begin{array}{l}\text { Effective in removing organic } \\
\text { matter, might need finishing stage. } \\
\text { No nutrient removal, must be } \\
\text { followed by post-processing for } \\
\text { this purpose. }\end{array}$ \\
\hline $\begin{array}{l}\text { Human and } \\
\text { ecosystem health }\end{array}$ & $\begin{array}{l}\text { Effluent needs post-processing, } \\
\text { usually by land disposal (where } \\
\text { allowed) or CWs. No significant } \\
\text { disinfection performed. }\end{array}$ & $\begin{array}{l}\text { Effective integration with existing } \\
\text { ecosystems, little disinfection (must } \\
\text { be followed by post-processing or } \\
\text { tertiary disinfection stage). }\end{array}$ & $\begin{array}{l}\text { Effluent highly compatible with } \\
\text { discharge into surface waters. } \\
\text { Depending on membrane, media } \\
\text { characteristics can provide some } \\
\text { degree of disinfection. }\end{array}$ & $\begin{array}{l}\text { Effluent usually needs a finissage } \\
\text { post-processing. Little } \\
\text { disinfection performed. }\end{array}$ \\
\hline Resources conservation & $\begin{array}{l}\text { Limited soil consumption } \\
\text { (underground systems), low to nil } \\
\text { energetic input, water is returned } \\
\text { with partial treatment to } \\
\text { groundwater (infiltration) or surface } \\
\text { waters (usually after CW finissage). }\end{array}$ & $\begin{array}{l}\text { Integrates treatment function with } \\
\text { ecosystems, low energetic input; } \\
\text { returns water to the natural cycle. }\end{array}$ & $\begin{array}{l}\text { Reduced soil consumption for } \\
\text { construction, high energy demand. } \\
\text { Low conservation. }\end{array}$ & $\begin{array}{l}\text { Reduced soil consumption for } \\
\text { construction, low energy demand. } \\
\text { Energy recovery. Effluent and } \\
\text { excess sludge high in nutrients } \\
\text { (could be used in agriculture). } \\
\text { Sludge can be processed for } \\
\text { nutrient recovery. }\end{array}$ \\
\hline Water reuse & $\begin{array}{l}\text { Water is returned to the natural cycle } \\
\text { with limited treatment. Possibility of } \\
\text { groundwater contamination } \\
\text { (organics, nitrates). }\end{array}$ & $\begin{array}{l}\text { Water is returned to the natural } \\
\text { cycle (ground and/or surface } \\
\text { water). Possible losses for high } \\
\text { evaporation in arid countries. }\end{array}$ & $\begin{array}{l}\text { Effluent water of high quality can } \\
\text { satisfy most non-drinking uses. }\end{array}$ & $\begin{array}{l}\text { Effluent water can be used in } \\
\text { irrigation or other local uses after } \\
\text { adequate postprocessing. }\end{array}$ \\
\hline $\begin{array}{l}\text { Nutrients and } \\
\text { materials recycling }\end{array}$ & $\begin{array}{l}\text { Bottom sludge containing nutrients } \\
\text { must be periodically evacuated. } \\
\text { Processing is necessary (e.g., } \\
\text { composting) before recycling. }\end{array}$ & $\begin{array}{l}\text { Nutrients are recycled into biomass. } \\
\text { This must be periodically removed } \\
\text { for recycling and proper CW } \\
\text { functioning. }\end{array}$ & $\begin{array}{l}\text { Process can be adapted for } \\
\text { nutrients removal. Low excess } \\
\text { sludge production. }\end{array}$ & $\begin{array}{l}\text { No nutrient removal. Sludge can be } \\
\text { postprocessed for nutrients } \\
\text { removal, energy (e.g., biodiesel) or } \\
\text { chemicals extraction. }\end{array}$ \\
\hline Energy/GHG emission & $\begin{array}{l}\text { Low energy requirements. Anaerobic } \\
\text { conditions may cause emissions of } \\
\text { methane and } \mathrm{CO}_{2} \text { in quantities that } \\
\text { are not usually worth recovering. }\end{array}$ & $\begin{array}{l}\text { Very low energy requirements and } \\
\text { emissions. Low GHG emissions if } \\
\text { anaerobiosis is avoided. }\end{array}$ & $\begin{array}{l}\text { High energy requirements, with } \\
\text { high, related GHG emissions. } \\
\text { Possibility of other N-related } \\
\text { GHG emissions. }\end{array}$ & $\begin{array}{l}\text { Low energy input. Energy recovery } \\
\text { as biogas (biohydrogen possible). } \\
\text { Uncollected/dispersed methane is } \\
\text { considered harmful GHG } \\
\text { emission. Transformation of biogas } \\
\text { to biomethane suggested is not } \\
\text { enough local heat users. }\end{array}$ \\
\hline
\end{tabular}


Table 2. Cont

\begin{tabular}{|c|c|c|c|c|}
\hline Issue Category & Septic Tanks (Imhoff \& Other) & Constructed Wetlands & MBRs & Anaerobic Processes (UASBs) \\
\hline \multicolumn{5}{|c|}{ Economical } \\
\hline Investment costs & Minimal & $\begin{array}{l}\text { Could be significant only for land } \\
\text { area (and connection system } \\
\text { to users). }\end{array}$ & $\begin{array}{l}\text { High. Although footprint is lower } \\
\text { than a traditional AS and } \\
\text { equivalent CW, membrane cost is } \\
\text { rather high. Needs connection } \\
\text { system to users. }\end{array}$ & $\begin{array}{l}\text { Low, especially for physical } \\
\text { infrastructure. Needs connection } \\
\text { system to users. }\end{array}$ \\
\hline$O$ and $M$ costs & $\begin{array}{l}\text { Minimal (only periodic evacuation of } \\
\text { sludge required). Some users "feed" } \\
\text { these systems with lyophilized } \\
\text { biomass to improve org. matter } \\
\text { degradation. }\end{array}$ & $\begin{array}{l}\text { Low (some pumping to facility } \\
\text { probably required). Biomass } \\
\text { removal and disposal. Personnel do } \\
\text { not need to receive } \\
\text { complex training. }\end{array}$ & $\begin{array}{l}\text { High, due to energy costs and } \\
\text { periodical membrane media } \\
\text { substitution/ cleaning. Personnel } \\
\text { need relatively complex training. }\end{array}$ & $\begin{array}{l}\text { Low. Personnel do not need } \\
\text { complex training. }\end{array}$ \\
\hline Efficiency (technology) & $\begin{array}{l}\text { Low efficiency, low cost solution. } \\
\text { Usually adopted as a first level of } \\
\text { sanitation in developing countries. }\end{array}$ & $\begin{array}{l}\text { Cost of technology per unit organic } \\
\text { pollutant removed is low. } \\
\text { Robustness of technology is good. }\end{array}$ & $\begin{array}{l}\text { Cost of technology per unit organic } \\
\text { pollutant removed is medium. } \\
\text { Robustness of technology high (if } \\
\text { proper maintenance performed). }\end{array}$ & $\begin{array}{l}\text { Cost of technology per unit organic } \\
\text { pollutant removed is low. } \\
\text { Robustness of technology } \\
\text { medium-high. }\end{array}$ \\
\hline Residuals management & $\begin{array}{l}\text { Excess biomass (sludge) and scum } \\
\text { must be periodically removed and } \\
\text { disposed. Depending on quantities, } \\
\text { could be processed for recovery of } \\
\text { energy/material. }\end{array}$ & $\begin{array}{l}\text { Biomass must be periodically } \\
\text { removed and disposed. Depending } \\
\text { on actual vegetation, could be } \\
\text { processed for recovery of } \\
\text { energy/material. }\end{array}$ & $\begin{array}{l}\text { Low excess sludge production, } \\
\text { some collection and } \\
\text { disposal required. }\end{array}$ & Very low excess sludge production. \\
\hline Population served & $\begin{array}{l}\text { Very low-sophisticated technology } \\
\text { can be built and managed by } \\
\text { poorly-skilled local population, } \\
\text { providing occupation and growth. }\end{array}$ & $\begin{array}{l}\text { Low sophisticated technology can } \\
\text { be built and managed by } \\
\text { poorly-skilled local population, } \\
\text { providing occupation and growth. }\end{array}$ & $\begin{array}{l}\text { Highly sophisticated technology; } \\
\text { structures can be built by } \\
\text { medium-skilled local population, } \\
\text { providing some occupation. } \\
\text { Operation will permanently require } \\
\text { skilled labor. }\end{array}$ & $\begin{array}{l}\text { Somewhat sophisticated } \\
\text { technology; structures can be built } \\
\text { by medium skilled local population, } \\
\text { providing some occupation. } \\
\text { Operation will permanently require } \\
\text { some skilled labor. }\end{array}$ \\
\hline
\end{tabular}


Table 2. Cont

\begin{tabular}{|c|c|c|c|c|}
\hline Issue Category & Septic Tanks (Imhoff \& Other) & Constructed Wetlands & MBRs & Anaerobic Processes (UASBs) \\
\hline \multicolumn{5}{|c|}{ Social } \\
\hline Public health & $\begin{array}{l}\text { Must not be directly accessible. Can } \\
\text { be supplemented by disinfection } \\
\text { treatments (solar, etc.). }\end{array}$ & $\begin{array}{l}\text { Facility must not be directly } \\
\text { accessible by citizens. Not much } \\
\text { disinfection provided by this } \\
\text { technology. Could be } \\
\text { supplemented by solar stage. }\end{array}$ & $\begin{array}{l}\text { Disinfection provided to a certain } \\
\text { degree. Removal of micropollutants } \\
\text { (including some pharmaceuticals } \\
\text { and endrocrine disruptors) } \\
\text { possible. }\end{array}$ & $\begin{array}{l}\text { Not much disinfection carried out } \\
\text { by the process. Further } \\
\text { post-processing required. }\end{array}$ \\
\hline Human settlement & $\begin{array}{l}\text { Applicable in rural settings, with } \\
\text { enough separation from people } \\
\text { served. No lower/upper limit to } \\
\text { service size. Should avoid direct } \\
\text { nuisance effects (odors, insects, etc.). }\end{array}$ & $\begin{array}{l}\text { Applicable mostly in rural/peri } \\
\text { urban settings, with separation } \\
\text { (distance) from people served. No } \\
\text { lower/upper limit to service size } \\
\text { (except area availability) Should } \\
\text { avoid direct nuisance effects } \\
\text { (odours, insects, etc.). }\end{array}$ & $\begin{array}{l}\text { Applicable in all settings (urban to } \\
\text { rural) once provisions are made to } \\
\text { avoid possible nuisance to } \\
\text { population served. }\end{array}$ & $\begin{array}{l}\text { Applicable in all settings. In urban } \\
\text { settings, it should be preferably } \\
\text { contained to avoid nuisances. }\end{array}$ \\
\hline Nuisance and aesthetics & $\begin{array}{l}\text { Predictable nuisances may include } \\
\text { odors from improperly built systems, } \\
\text { insects, and pests (rats, birds, etc.). } \\
\text { Aesthetics not a problem as these } \\
\text { systems are usually completely } \\
\text { underground. }\end{array}$ & $\begin{array}{l}\text { Predictable nuisances may include } \\
\text { odors, insects, and pests (rats, birds, } \\
\text { etc.). Aesthetics can be improved by } \\
\text { proper design and landscaping. }\end{array}$ & $\begin{array}{l}\text { Nuisances can consist of odors, } \\
\text { noise, and traffic. Odors can offend } \\
\text { resident population and be source } \\
\text { of unacceptance and complaint. } \\
\text { Appropriate measures should be } \\
\text { introduced since design stage. } \\
\text { Aesthetics can be improved by } \\
\text { landscaping and mimetization. }\end{array}$ & $\begin{array}{l}\text { Nuisances can consist of strong } \\
\text { odors, noise and traffic. Odors can } \\
\text { offend resident population and be } \\
\text { source of unacceptance and } \\
\text { complaint. Appropriate measures } \\
\text { should be introduced since design } \\
\text { stage. Aesthetics can be improved } \\
\text { by landscaping and mimetization. }\end{array}$ \\
\hline Planning & \multicolumn{4}{|c|}{$\begin{array}{l}\text { Proper, shared planning addressing the resident population's concerns should be enacted since the first moment. Often, proper and open communication } \\
\text { with stakeholders is the key for social acceptance. }\end{array}$} \\
\hline Operating fees & Extremely low. & $\begin{array}{l}\text { Low. Can easily be supported by } \\
\text { users. }\end{array}$ & $\begin{array}{l}\text { Medium-high. Can be supported by } \\
\text { motivated users with specific } \\
\text { objectives of water quality } \\
\text { (including recycling). }\end{array}$ & $\begin{array}{l}\text { Medium-low. Can be supported by } \\
\text { users. }\end{array}$ \\
\hline Government regulations & $\begin{array}{l}\text { Not allowed any longer in some } \\
\text { developed Countries. }\end{array}$ & $\begin{array}{l}\text { Process can comply with basic w.q. } \\
\text { (water quality) regulations. }\end{array}$ & $\begin{array}{l}\text { Process can comply with advanced } \\
\text { w.q. regulations. }\end{array}$ & $\begin{array}{l}\text { Process can comply with most w.q. } \\
\text { regulations. }\end{array}$ \\
\hline
\end{tabular}


Table 2. Cont

\begin{tabular}{|c|c|c|c|c|}
\hline Issue Category & Septic Tanks (Imhoff \& Other) & Constructed Wetlands & MBRs & Anaerobic Processes (UASBs) \\
\hline Citizens' attitude & $\begin{array}{l}\text { It could be well accepted in } \\
\text { developing countries as a first-stage } \\
\text { solution to basic sanitation. }\end{array}$ & $\begin{array}{l}\text { As a general rule, citizens will } \\
\text { usually support "natural" } \\
\text { treatment methods, especially if } \\
\text { they are convinced that no nuisance } \\
\text { will follow. }\end{array}$ & $\begin{array}{l}\text { Citizens tend to be wary of such } \\
\text { "high-rate" processes, as they might } \\
\text { fear that their control will not be as } \\
\text { spotless as initially declared, with } \\
\text { the possibility of nuisances arising. } \\
\text { Operator's prior reputation } \\
\text { will help. }\end{array}$ & $\begin{array}{l}\text { Notwithstanding the initial } \\
\text { perspective of resource recovery } \\
\text { attached to this technology, citizens } \\
\text { tend to be wary of similar processes } \\
\text { as they might fear that of nuisances } \\
\text { (esp. odors) could arise. Operator's } \\
\text { reputation demonstrated with prior } \\
\text { success cases will help. }\end{array}$ \\
\hline Remarks & $\begin{array}{l}\text { It could constitute the basic } \\
\text { component of a decentralized system } \\
\text { followed by finishing and } \\
\text { disinfection processes. }\end{array}$ & $\begin{array}{l}\text { CWs main limitation is related to } \\
\text { the surface area needed for } \\
\text { construction. CWs are better } \\
\text { compatible with conventional-type } \\
\text { collections systems with limited or } \\
\text { no source separation and relatively } \\
\text { diluted wastewater. }\end{array}$ & $\begin{array}{l}\text { MBRs main limitation is related to } \\
\text { their status of aerobic technology } \\
\text { (energy-intensive operation). } \\
\text { Anaerobic MBRs are being } \\
\text { developed, but their cost puts them } \\
\text { at a disadvantage compared to } \\
\text { other anaerobic processes such as } \\
\text { UASBs. A second limitation of } \\
\text { membrane processes is the cost of } \\
\text { the filtration medium and its } \\
\text { fouling tendency in time, reducing } \\
\text { operating life. Compatible with } \\
\text { source separation (esp. with the } \\
\text { greywater component) and } \\
\text { moderately water-reduced systems. }\end{array}$ & $\begin{array}{l}\text { UASBs require less surface area } \\
\text { compared to CWs, and much less } \\
\text { operating energy than MBRs. The } \\
\text { greatest advantages of UASBs is } \\
\text { their construction and operational } \\
\text { simplicity, and the possibility of } \\
\text { energy (biogas, biohydrogen) } \\
\text { recovery. Originally mostly used in } \\
\text { warm regions, their applicability at } \\
\text { low temperatures (down to } 10^{\circ} \mathrm{C} \text { ) } \\
\text { has nevertheless been shown. } \\
\text { Effluent could be processed for } \\
\text { nutrients recovery. }\end{array}$ \\
\hline
\end{tabular}




\section{Sustainable Wastewater Collection and Transport}

As discussed in the introduction, currently-used wastewater transport systems bear a substantial (perhaps the largest) share of environmental impact in UWSs [3,9]. In addition, traditional wastewater management is based on a disadvantageous approach, since its operation depends on high water usage and excessive waste dilution. This not only implies a higher cost of treating diluted wastewater (due to its larger volumes, and thus larger facilities needed), low energy-efficiency (bigger pumping and conveying facilities, implying increased operational costs for users) and less efficient energy recovery from wastewater (due to technological and process limitations); it also uses large volumes of treated, mostly drinking-quality water merely as a transport means for primary waste and system flushing. Otterpohl and co-workers estimated that by enacting source control and differential water use, new decentralized technologies could manage wastewater systems with just around $20 \%$ of the current water demand [54], which is usually drinking grade. Traditional systems are strongly dependent on electrical energy supplies for pumping, potentially making the system poorly resilient during exceptional events and power failures $[55,56]$. An underlying assumption of the subsequent discussion is that all wastewater is collected and transported in separate (domestic vs. stormwater) sewer systems. In the real world, however, combined sewer systems are still normally used (especially in urban areas), exacerbating all the issues that will be discussed in this section.

\subsection{Source Control and Improved Sustainability}

Separation of different domestic wastewater streams, aimed at differentiated on/off-site processing for resource recovery/recycling, is now recognized as one of the most promising concepts to re-establish sustainable management in carbon, nutrient, energy, and water cycles [23,54], although there is still ample resistance to the generalized adoption of this paradigm. It is well known that domestic wastewater can be divided into two major streams: concentrated blackwater (feces and urine, sometimes mixed with kitchen refuse), and less concentrated greywater from various washing activities. Blackwater can be further divided into urine (yellow water) and feces (brownwater) using urine diverting toilets or urinals.

Source separation per se avoids unnecessary and anti-economical waste dilution. The key principle advocating source separation is that energy and nutrients (mostly contained in blackwater) can be recovered more easily and efficiently from concentrated streams. Most of the pathogens and micropollutants (such as pharmaceuticals and endocrine disruptors) are also contained in blackwater, therefore a concentrated, more easily containable waste stream will minimize the chances of external contamination. Table 3 summarizes general characteristics of separated domestic wastewater streams. In general, the high concentration of separated blackwater makes anaerobic treatment (with recovery of energy in the form of biogas and nutrients, with post-processing) a very attractive treatment option, as discussed in Section 3.3.

Table 3. Average characteristics of domestic, separated wastewater streams (Data from $[57,58]$ ).

\begin{tabular}{|c|c|c|c|c|c|c|c|}
\hline Source & $\begin{array}{l}\text { Volume } \\
\text { (L/cap/d) }\end{array}$ & $\begin{array}{c}\text { TSS Range } \\
(\mathrm{mg} / \mathrm{L})\end{array}$ & $\begin{array}{l}\text { COD Range } \\
(\mathrm{mg} / \mathrm{L})\end{array}$ & $\begin{array}{l}\text { N Range } \\
(\mathrm{mg} / \mathrm{L})\end{array}$ & $\begin{array}{l}\text { P Range } \\
(\mathrm{mg} / \mathrm{L})\end{array}$ & $\begin{array}{c}\text { Metals \& } \\
\text { Micropollutants }\end{array}$ & Pathogens \\
\hline Blackwater & $1-7$ & $16,000-125,000$ & $5000-93,000$ & $1500-16,000$ & $500-3000$ & $\begin{array}{c}\text { High } \\
(\sim 10 \mathrm{mg} / \mathrm{cap} / \mathrm{d})\end{array}$ & High \\
\hline Greywater & $70-150$ & $100-800$ & $200-450$ & $6-22$ & $0.4-8$ & $\begin{array}{c}\text { Very High } \\
(10 \mathrm{mg} / \mathrm{cap} / \mathrm{d})\end{array}$ & Low \\
\hline Urine & $0.5-2.5$ & $15,000-30,000$ & $4000-11,000$ & $1800-18,000$ & 200-4000 & $\begin{array}{c}\text { Very low } \\
(<1 \mathrm{mg} / \mathrm{cap} / \mathrm{d})\end{array}$ & Medium-Low \\
\hline
\end{tabular}

Less concentrated greywater streams could serve as alternative water sources after minor onsite processing. While containing but a minor proportion of nutrients, greywater contains a major fraction of household-originated heavy metals, from dust and chemicals (detergents and personal care products) to fats/grease from kitchen washwater [58]. Pathogens content is low, likely lower than in effluent 
water from a WWTP. Pre-treatment is usually needed, to avoid clogging of the processing system by greases, or the creation of bad odors. By allowing solids and grease separation, basic septic tanks could be an appropriate technique for most greywater pretreatment systems in rural (as well as urban) areas. Screens or filters could also be used. Processes developed for greywater treatment could include sand or membrane filtration combined with appropriate pre-treatment, coagulation and advanced oxidation, and extensive or intensive biological systems (i.e., soil filtration, constructed wetland system, membrane bioreactors, etc.). Removal efficiency for Biological Oxygen Demand (BOD) is typically around 90-99\%, somewhat lower for COD. Locally recycled water could be used for toilet flushing, landscaping (i.e., lawn irrigation), aquifer augmentation (infiltration in the subsurface). Irrigation of foodcrops should avoid direct contact with the edible part of the plants.

The advantages of source separation can be further enhanced by adopting extreme water-saving measures, such as low-flush devices specifically designed to reduce water volumes needed for waste solids mobilization and low-flow toilets (from 6-12 L/flush down to 0.8-2 L/flush). With application of low-flow devices, COD in urban sewer systems could increase significantly compared to normally observed levels. With joint application of source separation, extremely low-flush devices (similar to those used in airplanes, currently being developed for domestic use), and non-traditional conveyance methods (i.e., vacuum sewers, discussed below), such values could increase more than tenfold (up to 10-15 g/L), resulting in dramatic effects on the current paradigms of wastewater management.

To draw energy and material balances of centralized and source-separated sanitation concepts, quantitative tools (similar to those used for wastewater technology selection) can be used [59]. The environmental impact contribution of the sewer system, often erroneously assumed as negligible, has been shown to be more relevant than that of WWTPs on a large part of analyzed projects. Tervahauta et al. [23] calculated primary energy consumptions of standardized, centralized, and decentralized collection systems based on Dutch conditions; their findings show that the highest primary energy consumption of $914 \mathrm{MJ} /$ cap/year occurs within centralized sanitation cases. By introducing source-separation of urine, direct energy consumption can decrease to $687 \mathrm{MJ} / \mathrm{cap} / \mathrm{year}$. Source-separating blackwater, kitchen refuse, and greywater would result in primary energy consumption of $767 \mathrm{MJ} / \mathrm{cap} /$ year, reduced to $522 \mathrm{MJ} / \mathrm{cap} /$ year when including indirect energy gain from water saving, reuse, and nutrient recovery. With systems based on vacuum, urine diverting toilets would lower consumption to $555 \mathrm{MJ} / \mathrm{cap} /$ year. Considering all indirect energy gains from water saving and reuse, nutrient recovery, and decreased energy consumption, the lowest calculated energy consumptions were indicated as of $208 \mathrm{MJ} /$ cap/year (gravity-based systems) and $190 \mathrm{MJ} / \mathrm{cap} /$ year (vacuum-based systems). The calculations did not include heat recovery from sewer connectors.

Source separation, by reducing volumes of liquid waste, can not only reduce the amount of energy necessary to operate the sewerage collection system (lower pumped volumes) but will also allow a shift to more sustainable (e.g., anaerobic vs. aerobic) energy (e.g., biogas, biohydrogen) and resources recovery ( $\mathrm{N}$ and $\mathrm{P}$, primarily) final processing technologies. This will also require lower primary energy inputs (e.g., avoiding aeration), and reduce the amounts of by-products (excess sludge) that should be handled, at a cost. A further paradigm switch in the technology normally used for wastewater collection systems could improve the overall degree of sustainability of these systems.

\subsection{Vacuum Sewerage System: Benchmark of Sustainable Collection?}

Vacuum sewage systems (VSS) have been around for many years, but they only recently started to be appreciated as a possible, sustainable technological solution for wastewater collection. Vacuum sewers [60] are suitable to fulfil the original purpose of urban sewerage (limit human contact with fecally, or other-activity contaminated water) with full environmental and health protection, while reducing seepage and odors, and generating savings in energy consumption and operational costs. Such systems provide major advantages in applications such as: existing residential areas with septic tanks or development of new residential areas; sewers located near lakes, rivers, coastlines, and flood plains, flat terrain or rolling hills with small elevation changes, high groundwater tables; unfavorable 
soil conditions (sand, rock, risk of soil settlement) and ground subsidence; weekend/vacation housing or recreational establishments with highly variable wastewater flows; and sewers rehabilitation instances [61].

VSSs are based on the principle of using the differential pressure in a vacuum-maintained pipeline to collect wastewater and transport it to a final station, from where it can be sent to local treatment, or gradually further conveyed to a centralized or decentralized WWTP. In VSSs, vacuum is generated at a single, central point in the system, thus requiring only one point of energy consumption, largely eliminating the need for inspection manholes, simplifying power sourcing, and reducing construction and ongoing operational costs. Construction of such systems, on the other hand, entail savings by avoiding deep and large excavations, since smaller diameter continuous pipes, very low gradients, and elimination of intermediate pumping stations and access manholes are implied by design. Usually, about 200 connections or more, within a radius up to $4-5 \mathrm{~km}$ (in ideal terrain) can be handled by a single vacuum point $[62,63]$ that can be arranged in series.

Many published case studies define the limits and benefits of these systems [62-65]. A comparative analysis of two alternative projects for the construction of a sewerage system in a rural village of about 2000 P.E. in Romania, including a wastewater treatment plant, benchmarked a VSS system compared to a classical solution alternative with intermediate pumping stations [62]. From an investment point of view, the VSS proved to be about $24 \%$ cheaper than the gravity system, while additional savings (due to lower operational energy costs) could be expected during its operational lifetime. Significant carbon emissions reduction could be achieved with the vacuum solution, both in the construction and operating phases. Since the same technology for wastewater treatment was considered, WWTP flow and energy consumption was considered constant [64]. From the previous discussion, however, one could also infer that more energy-efficient WW treatment technologies could be used in such a case, improving the overall system sustainability. VSS systems offer some inherent benefits compared to traditional systems, whose economic value has not been considered in the previous analysis: among them, the elimination of both infiltration into the pipes (reduction of parasite flow) and leakage (reduced risk of groundwater contamination) due to tightly sealed pipes, absence of overflow points (no parasite flows, thus reduced risk to environmentally sensitive areas), lower maintenance needs (reduced opportunities for clogging and settling of solids), lower opportunities (immediate detection) of illegal connections, better response to discontinuous service (pipes can be left dry without problems), and others.

A study conducted in Egypt compared detailed hydraulic designs for conventional and vacuum sewerage systems in 28 agricultural villages in that country, comparing cost components of both systems by means of statistical analysis [65]. While both gravity and VSS systems total costs depend on population and area served, the study showed that the investment cost of vacuum systems was always found to be lower than that of gravity systems. While analysis of operational and maintenance cost was not fully completed, the study recommended construction of vacuum sewerage purely from the observation of the deriving environmental advantages.

As pointed out by Little [65], VSSs application has some distinct advantages in developing countries, in that it can be used by people who are poor and cannot afford tissue paper (newspaper, stones, etc. used for anal cleansing in poor areas may cause blockages of gravity sewers); be used with very little water as the pipes do not need to be flushed (enabling water savings and allowing the adoption of more energy-efficient treatment technology); and be laid at flatter gradients than gravity systems (since deep trench excavations are not needed, the system is cheaper to construct; also, its labor input could be much larger-benefitting the local community during the construction phase, as shallower trenches can be hand-dug).

\section{Discussion}

While currently adopted approaches to individual water services (i.e., water resources, drinking water, wastewater, and stormwater) have so far led to great improvements in public health and 
environmental protection (first in western, and then in developing countries), sustainable solutions are now required in view of increased resource demand from a growing global population. Water usage is growing at double the rate of population increase, therefore paradigmatic shifts based on holistic management (to maximize use and recovery of water, energy, nutrients, and materials) are needed [66].

Traditional water management approaches classify four types of services: surface water/groundwater (available resources), supply (drinking) water, wastewater, and stormwater, and each one is managed according to specific, largely independent, rules. For example, all domestic supply water is treated to drinking water standards, water is used linearly (only once) before discharge, and wastewater is treated as waste (to be eliminated regardless of its potential value due to unexploited constituents (energy, nutrients, etc.)). Stormwater, when not mixed with wastewater, is largely handled as a nuisance factor to be taken out of sight as soon as possible. Only once complex water issues could be evaluated holistically will any comprehensive water system become sustainable and balanced with local economic activities and ecological services [67].

\section{Consequences of Decentralization}

Centralized water systems' advantage is uniformity, assuring that they meet water demand and quality standards in a large service area. They are-by definition-large, and subject to a certain degree of inertia in financial, organizational, system operations, and technical matters. Recently, existing and projected water shortages and related factors have forced the water community to focus attention on the need for water reuse. Decentralized infrastructure could also offer significant benefits by spreading the risks of drought and extreme events among multiple locations. It is therefore a more climate-resilient option to provide a primary public service, and such systems will have a lower vulnerability from accidental extreme events, including natural disasters, power outages, and deliberate sabotage (i.e., terrorist activities).

The US Environmental Protection Agency (EPA) has recognized that "decentralized wastewater systems may provide a cost-effective and long-term option for meeting public health and water quality goals, particularly in less densely populated areas" [68]. Implications of decentralization on wastewater management systems are not limited to the possible adoption of more efficient technologies for local resource recycle and recovery, and to enhanced sustainability of local ecosystems. A decentralization choice relates to planning, decision making, design of infrastructure networks, and to arrangements for systems operation and maintenance. Practically, it can be a way of strengthening the role of citizens in local government and a means of incisively addressing local environmental and health concerns, and it can lead to improved services and more accountable service providers. If innovation in alternative technologies and practices becomes necessary, this would more likely be implemented in small, decentralized systems, as capital investment for decentralized systems is generally less than for centralized ones. Although supposed to bring positive impacts on the management of urban water systems, decentralized systems involve highly relevant changes in the way planning and decisions concerning the management of water resources, as well as infrastructure, operations, and maintenance, are made. Resistance to this novel approach is therefore to be expected (even from technical personnel) due to tradition, training and habit.

Decentralized systems will tend to be compatible with local water use (reuse) requirements, where locally treated water and its nutrient content could increase agricultural productivity or (in more urban areas) be used as a substitute for treated supply water for landscaping or groundwater resources replenishment. Table 4 summarizes reuse opportunities for locally reclaimed water; some of these may be possible on a seasonal-only basis, depending on local climate and conditions.

Decentralization emphasizes a holistic approach, taking advantage of the benefits of reducing amounts of waste at source, and improving recycling or reuse at the site, by keeping the wastewater collection component as low as possible and focusing primarily on treatment and disposal of the minimized amounts of wastewater. It has been estimated that collection and treatment costs can 
thus be reduced by more than $60 \%$ compared to those of centralized system, particularly in small communities with low population densities [69].

Table 4. Possible local reuses of reclaimed water.

\begin{tabular}{|c|c|c|}
\hline Application & Comments & $\begin{array}{c}\text { Additional Infrastructure } \\
\text { Required }\end{array}$ \\
\hline Agriculture (irrigation) & $\begin{array}{l}\text { Irrigation is the most popular water reuse } \\
\text { application in the world. Appropriate treatment } \\
\text { practices are determined by local pedology, crops, } \\
\text { and legislation. Usually seasonal. }\end{array}$ & $\begin{array}{l}\text { Distribution system, } \\
\text { pumping. }\end{array}$ \\
\hline $\begin{array}{l}\text { Lanscaping (irrigation) } \\
\text { and surface storage } \\
\text { (ponds) }\end{array}$ & $\begin{array}{l}\text { Irrigation of parks and residential greens, golf } \\
\text { courses, cemeteries; roadside vegetation is } \\
\text { another very popular water reuse. Surface } \\
\text { storage (vegetated ponds) of partially treated } \\
\text { water can be used for the creation of aesthetic } \\
\text { value in peri-urban housing developments when } \\
\text { seasonal irrigation is not needed. }\end{array}$ & $\begin{array}{l}\text { Distribution system, } \\
\text { pumping, creation of } \\
\text { artificial basins. }\end{array}$ \\
\hline $\begin{array}{l}\text { Other urban } \\
\text { (non irrigation) }\end{array}$ & $\begin{array}{l}\text { Street washing, fire protection, air conditioning } \\
\text { cooling, car washing, and commercial laundering } \\
\text { are examples of urban non-irrigation applications. } \\
\text { Non seasonal. }\end{array}$ & $\begin{array}{l}\text { Distribution system, } \\
\text { pumping, and storage (can } \\
\text { be surface ponds above). }\end{array}$ \\
\hline $\begin{array}{l}\text { Environmental and } \\
\text { recreation }\end{array}$ & $\begin{array}{l}\text { Wildlife habitats and wetlands, and river flow } \\
\text { enhancement/augmentation (may contribute to } \\
\text { indirect potable use). Creation of lakes and ponds } \\
\text { for recreational use. Non seasonal. }\end{array}$ & $\begin{array}{l}\text { Distribution system, } \\
\text { pumping, creation of } \\
\text { artificial basins. }\end{array}$ \\
\hline Groundwater recharge & $\begin{array}{l}\text { Restoration of groundwater levels and control of } \\
\text { saltwater or blackish water intrusion into } \\
\text { freshwater aquifer. May contribute to indirect } \\
\text { potable uses. Non seasonal. }\end{array}$ & $\begin{array}{l}\text { Distribution/infiltration } \\
\text { system. }\end{array}$ \\
\hline Industrial applications & $\begin{array}{l}\text { Cooling uses in power plants, oil refineries, and } \\
\text { manufacturing facilities. Use as process water } \\
\text { after suitable treatment. }\end{array}$ & $\begin{array}{l}\text { Distribution system, } \\
\text { pumping, and additional } \\
\text { treatment (process water). }\end{array}$ \\
\hline $\begin{array}{l}\text { Domestic and } \\
\text { commercial } \\
\text { (toilet flushing) }\end{array}$ & $\begin{array}{l}\text { Reclaimed greywater can be used, after } \\
\text { preliminary processing, for toilet flushing or } \\
\text { outdoors surfaces cleaning. Non seasonal. }\end{array}$ & $\begin{array}{l}\text { Dual distribution system, } \\
\text { pumping, and additional } \\
\text { disinfection treatment. }\end{array}$ \\
\hline Direct potable use & $\begin{array}{l}\text { Documented direct potable reuse applications } \\
\text { exist in the capitals of Namibia, Windhoek, and } \\
\text { Singapore. Tertiary-treated wastewater is } \\
\text { discharged to surface reservoirs, where it mixes } \\
\text { with freshwater and undergoes heavy RO and } \\
\text { disinfection supply-grade treatment before being } \\
\text { fed to the water distribution system. This } \\
\text { solution is being also studied in other } \\
\text { water-deficient areas (California). Requires ample } \\
\text { consensus on the part of users. Non seasonal. }\end{array}$ & $\begin{array}{l}\text { Tertiary wastewater } \\
\text { treatment, surface storage, } \\
\text { advanced drinking-grade } \\
\text { treatment, and pumping. }\end{array}$ \\
\hline
\end{tabular}

\section{Conclusions}

This paper analyzed the needs, technological options, and contribution to water management of decentralized systems. Because of the increased demand for high quality (human supply) water, and future variability and uncertainty concerning the amounts of fresh water that will available following climate change effects and population concentration in larger urban areas, the need for new water resources is becoming an impending reality. In addition, the improved use of available natural resources (energy, materials, and nutrients) is also being advocated to improve the sustainability of modern development, in compliance of the new paradigm of "circular economy". Wastewater 
reclamation, reuse, and resource recovery have been used in limited applications so far, but this will become a necessary, generalized fact of life if a sustainable future is envisioned. It is the opinion of many researchers that decentralization of water resources management could be a desirable and sometimes unavoidable approach to providing a local (and by extension, regional) appropriate solution based on a forward and global view.

In analyzing sustainability of available suitable technologies (Section 3), different dimensions should be taken into account (in particular, local issues), as discussed in Section 3.4. There is no fixed or universal solution to the technological issue; on the contrary, all relevant studies demonstrated there are varying degrees of sustainability in the way a technology is selected and operated, to avoid exporting problems over time or space.

Increased sustainability of wastewater collection and transport is a key issue under general discussion, with potential for vast improvements in energy efficiency and resource recovery potential of decentralized urban wastewater systems. Source control, separation, and the adoption of alternative conveyance paradigms have been discussed in Section 4. As reported by several researchers, the adoption of these alternative solutions could significantly tighten the "closed loop" circle of resource recovery and reuse in decentralized systems.

Decentralized solutions in general will tend to be compatible with local water use and reuse requirements, where locally treated water could support agricultural productivity or (in more urban areas) be used as a substitute for drinking-quality supply water for compatible uses. A review of existing literature on the consequences of decentralization (Section 5) reveals a generally positive attitude towards these systems.

Acknowledgments: No special funding was received for this study.

Conflicts of Interest: The author declares no conflict of interest.

\section{References}

1. Capodaglio, A.G.; Callegari, A.; Cecconet, D.; Molognoni, D. Sustainability of decentralized wastewater treatment technologies. Water Pract. Technol. 2017, 12. [CrossRef]

2. UNDP Millennium Development Goals Website 2017. Available online: http://www.undp.org/content/ undp/en/home/sustainable-development-goals.html (accessed on 16 March 2017).

3. Risch, E.; Gutierrez, O.; Roux, P.; Boutin, C.; Corominas, L. Life cycle assessment of urban wastewater systems: Quantifying the relative contribution of sewer systems. Water Res. 2015, 77, 35-48. [CrossRef] [PubMed]

4. Parkinson, J.; Tayler, K. Decentralized wastewater management in peri-urban areas in low-income countries. Environ. Urban. 2003, 15, 75-90. [CrossRef]

5. Capodaglio, A.G.; Ghilardi, P.; Boguniewicz-Zablocka, J. New paradigms in urban water management for conservation and sustainability. Water Pract. Technol. 2016, 11, 176-186. [CrossRef]

6. Capodaglio, A.G.; Callegari, A. Domestic wastewater treatment with a decentralized, simple technology biomass concentrator reactor. J. Water Sanit. Hyg. Dev. 2016, 6. [CrossRef]

7. Brown, V.; Jackson, D.W.; Khalifé, M. 2009 Melbourne metropolitan sewerage strategy: A portfolio of decentralised and on-site concept designs. Water Sci. Technol. 2010, 62, 510-517. [CrossRef] [PubMed]

8. Istenic, D.; Bodík, I.; Bulc, T. Status of decentralised wastewater treatment systems and barriers for implementation of nature-based systems in central and eastern Europe. Environ. Sci. Pollut. Res. Int. 2015, 22, 12879-12884. [CrossRef] [PubMed]

9. Libralato, G.; Volpi Ghirardini, A.; Avezzù, F. To centralise or to decentralise: An overview of the most recent trends in wastewater treatment management. J. Environ. Manag. 2011, 94, 61-68. [CrossRef] [PubMed]

10. UNEP. Environmentally Sound Technologies for Wastewater and Stormwater Management: An International Source Book; IWA Publishing, The United Nations Environment Programme, International Environmental Technology Centre: London, UK; Osaka, Japan, 2002.

11. Novotny, V.; Brown, P. (Eds.) Cities of the Future: Towards Integrated Sustainable Water and Landscape Management; IWA Publishing: London, UK, 2007. 
12. Chen, R.; Wang, X.C. Cost-benefit evaluation of a decentralized water system for wastewater reuse and environmental protection. Water Sci. Technol. 2009, 59, 1515-1522. [CrossRef] [PubMed]

13. Opher, T.; Friedler, E. Comparative LCA of decentralized wastewater treatment alternatives for non-potable urban reuse. J. Environ. Manag. 2016, 182, 464-476. [CrossRef] [PubMed]

14. Van Loosdrecht, M.C.M.; Brdjanovic, D. Anticipating the next century of wastewater treatment. Science 2014, 344, 1452-1453. [CrossRef] [PubMed]

15. Novotny, V.; Imhoff, K.R.; Olthof, O.; Krenkel, P.A. Karl Imhoff's Handbook of Urban Drainage and Wastewater Disposal; Wiley: New York, NY, USA, 1989; p. 416.

16. Capodaglio, A.G.; Conti, F.; Fortina, L.; Pelosi, G.; Urbini, G. Assessing the environmental impact of WWTP expansion: Odour nuisance and its minimization. Water Sci. Technol. 2002, 46, 339-346. [PubMed]

17. Torretta, V.; Schiavon, M.; Papa, E.A.; Caruson, P.; Capodaglio, A.G. Removal of odorous sulphur compounds from industrial gases by biotrickling filters. Rev. Ambient. Água 2016, 11, 499-507. [CrossRef]

18. Beijing Water Authority (BWA). Data on Water Distribution and Use in Beijing, China. Available online: http://www.bjwater.gov.cn/ (accessed on 14 February 2014).

19. Wang, G.S.; Xia, J. Sustainable water resources exploitation and management in Beijing. In Sustainable Water Management Solutions for Large Cities; Savic, D., Marino, M.A., Savenije, H.H.G., Bertoni, J.C., Eds.; IAHS Publication 293; IAHS Press, Centre for Ecology and Hydrology: Wallingford, UK, 2005.

20. Van Dijk, M.P.; Liang, X. Case Study Brief_Beijing Managing Water for the Eco City of the Future. Switch Managing Water for the City of the Future; Final Report Annex; UNESCO-IHE: Delft, The Netherlands, 2012.

21. United States Environmental Protection Agency (US EPA). Decentralized Wastewater Treatment Systems; A Program Strategy; EPA 832-R-05-002; United States Environmental Protection Agency, Office of Water: Washington, DC, USA, 2005.

22. Capodaglio, A.G.; Callegari, A.; Lopez, M.V. European framework for the diffusion of biogas uses: Emerging technologies, acceptance, incentive strategies, and institutional-regulatory support. Sustainability 2016, 8 , 298-308. [CrossRef]

23. Tervahauta, T.; Hoang, T.; Hernandez, L.; Zeeman, G.; Buisman, C. Prospects of source-separation-based sanitation concepts: A model-based study. Water 2013, 5, 1006-1035. [CrossRef]

24. Mueller, R.A. Overview of decentralized wastewater treatment applications in Germany. State of the art-Future developments. In Proceedings of the International Conference on Sustainable Integrated Wastewater Treatment \& Reuse in the Mediterranean, Sharm-el-Sheik, Egypt, 1-2 December 2014.

25. Suriyachan, C.; Nitivattananon, V.; Amin Nurul, A.T.M. Potential of decentralized wastewater management for urban development: Case of Bangkok. Habitat Int. 2012, 36, 85-92. [CrossRef]

26. Go, E.; Demir, I. Cost analysis of alternative methods for wastewater handling in small communities. J. Environ. Manag. 2006, 79, 357-363.

27. Maurer, M.; Rothenberger, D.; Larsen, T.A. Decentralised wastewater treatment technologies from a national perspective: At what cost are they competitive? Water Sci. Technol. 2005, 5, 145-154.

28. Wang, S. Values of decentralized systems that avoid investments in idle capacity within the wastewater sector: A theoretical justification. J. Environ. Manag. 2014, 136, 68-75. [CrossRef] [PubMed]

29. Maurer, M.; Wolfram, M.; Anja, H. Factors affecting economies of scale in combined sewer systems. Water Sci. Technol. 2010, 62, 36-41. [CrossRef] [PubMed]

30. Fane, A.G.; Fane, S.A. The role of membrane technology in sustainable centralised wastewater systems. Water Sci. Technol. 2005, 51, 317-325. [PubMed]

31. Capodaglio, A.G.; Callegari, A.; Molognoni, D. Online monitoring of priority and dangerous pollutants in natural and urban waters: A state-of-the-art review. Manag. Environ. Qual. 2016, 27, 507-536. [CrossRef]

32. Chong, M.N.; Ho, A.N.M.; Gardner, T.; Sharma, A.K.; Hood, B. Assessing decentralised wastewater treatment technologies: Correlating technology selection to system robustness, energy consumption and GHG emission. J. Water Clim. Chang. 2013, 4, 338-347. [CrossRef]

33. Mander, U.; Kuusemets, V.; Öövel, M.; Mauring, T.; Ihme, R.; Pieterse, A.J. Wastewater purification efficiency in experimental treatment wetlands in Estonia. In Transformations of Nutrients in Natural and Constructed Wetlands; Vymazal, J., Ed.; Backhuys Publishers: Leiden, The Netherlands, 2001; pp. 201-224.

34. Masi, F.; Caffaz, S.; Ghrabi, A. Multi-stage constructed wetland systems for municipal wastewater treatment. Water Sci. Techol. 2013, 67, 1590-1598. [CrossRef] [PubMed] 
35. Capodaglio, A.G.; Hlavínek, P.; Raboni, M. Physico-chemical technologies for nitrogen removal from wastewaters: A review. Rev. Ambient. Água 2015, 10. [CrossRef]

36. Judd, S. Principles and application of membrane bio reactors for water and wastewater treatment. In the MBR Book, 2nd ed.; Butterworth-Heinemann: Oxford, UK, 2011; p. 497.

37. Capodaglio, A. Wet-weather transient impacts on wastewater treatment. In Urban Water Management; Arsov, R., Ed.; Kluwer Academic Publishers B.V.: Dordrecht, The Netherlands, 2002.

38. Meuler, S.; Paris, S.; Hackner, T. Membrane bio-reactors for decentralized wastewater treatment and reuse. Water Sci. Technol. 2008, 58, 285-294. [CrossRef] [PubMed]

39. Matulova, Z.; Hlavinek, P.; Drtil, M. One-year operation of single household membrane bioreactor plant. Water Sci. Technol. 2010, 61, 217-226. [CrossRef] [PubMed]

40. Capodaglio, A.G.; Hlavínek, P.; Raboni, M. Advances in wastewater nitrogen removal by biological processes: State of the art review. Rev. Ambient. Água 2016, 11. [CrossRef]

41. Abegglen, C.H.; Ospelt, M.; Siegrist, H. Biological nutrient removal in a small-scale MBR treating household wastewater. Water Res. 2008, 42, 338-346. [CrossRef] [PubMed]

42. De Cazes, M.; Abejón, R.; Belleville, M.P.; Sanchez-Marcano, J. Membrane bioprocesses for pharmaceutical micropollutant removal from waters. Membranes 2014, 4, 692-729. [CrossRef] [PubMed]

43. Capodaglio, A.G.; Suidan, M.; Venosa, A.D.; Callegari, A. Efficient degradation of MtBE and other gasoline-originated compounds by means of a biological reactor of novel conception: Two case studies in Italy and the USA. Water Sci. Technol. 2010, 61, 807-812. [CrossRef] [PubMed]

44. Capodaglio, A.G.; Callegari, A. Onsite management of tanker ships' rinse water by means of a compact bioreactor. Water Pract. Technol. 2015, 10, 681-687. [CrossRef]

45. Scott, D.; Hidaka, T.; Campo, P.; Kleiner, E.; Suidan, M.T.; Venosa, A.D. Biological nitrogen and carbon removal in a gravity flow biomass concentrator reactor for municipal sewage treatment. Chemosphere 2013, 90, 1412-1418. [CrossRef] [PubMed]

46. Appels, L.; Baeyens, J.; Degrève, J.; Dewil, R. Principles and potential of the anaerobic digestion of waste-activated sludge. Prog. Energy Combust. Sci. 2008, 34, 755-781. [CrossRef]

47. Capodaglio, A.G.; Ranieri, E.; Torretta, V. Process enhancement for maximization of methane production in codigestion biogas plants. Manag. Environ. Qual. 2016, 27, 289-298. [CrossRef]

48. Zeeman, G.; Kujawa, K.; de Mes, T.; Hernandez, L.; de Graaff, M.; Abu-Ghunmi, L.; Mels, A.; Meulman, B.; Temmink, H.; Buisman, C.; et al. Anaerobic treatment as a core technology for energy, nutrients and water recovery from source-separated domestic waste(water). Water Sci. Technol. 2008, 57, 1207-1212. [CrossRef] [PubMed]

49. Lettinga, G.; Roersma, R.; Grin, P. Anaerobic treatment of raw domestic sewage at ambient temperatures using a granular bed UASB reactor. Biotech. Bioeng. 1983, 25, 1701-1723. [CrossRef] [PubMed]

50. Seghezzo, L.; Zeeman, G.; van Liel, J.B.; Hamelers, H.M.V.; Lettinga, G. A review: The anaerobic treatment of sewage in UASB and EGSB reactors. Biores. Technol. 1998, 65, 175-190. [CrossRef]

51. De Graaff, M.S.; Temmink, H.; Zeeman, G.; Buisman, C.J.N. Anaerobic treatment of concentrated black water in a UASB reactor at a short HRT. Water 2010, 2, 101-119. [CrossRef]

52. United Nations (UN). Report of the World Commission on Environment and Development. "Our Common Future"; Annex to document A/42/427; Development and International Co-operation Environment, United Nations: New York, NY, USA, 1987.

53. Muga, H.E.; Mihelcic, J.R. Sustainability of wastewater treatment technologies. J. Environ. Manag. 2008, 88, 437-447. [CrossRef] [PubMed]

54. Otterpohl, R.; Braun, U.; Oldenburg, M. Innovative technologies for decentralised wastewater management in urban and peri-urban areas. In Proceedings of the 5th Specialised Conference on Small Water and Wastewater Treatment Systems, Istanbul, Turkey, 24-26 September 2002.

55. Blackmore, J.M.; Plant, R.A.J. Risk and resilience to enhance sustainability with application to urban water systems. Water Resour. Plan. Manag. 2008, 134, 224-233. [CrossRef]

56. Graham, S. Disrupted Cities: When Infrastructure Fails; Routledge: New York, NY, USA, 2010; p. 191.

57. Eriksson, E.; Auffarth, K.; Henze, M.; Ledin, A. Characteristics of grey wastewater. Urban Water 2002, 4, 85-104. [CrossRef]

58. Kujawa-Roeleveld, K.; Zeeman, G. Anaerobic treatment in decentralised and source-separation-based sanitation concepts. Rev. Environ. Sci. Bio Technol. 2006, 5, 115-139. [CrossRef] 
59. Benetto, E.; Nguyen, D.; Lohmann, T.; Schmitt, B.; Schosseler, P. Life cycle assessment of ecological sanitation system for small-scale wastewater treatment. Sci. Total Environ. 2009, 407, 1506-1516. [CrossRef] [PubMed]

60. Airvac Inc. Vacuum Sewers, Airvac Webpage 2013. Available online: http://www.airvac.com/info_vacuum. htm/ (accessed on 25 January 2017).

61. Aqseptence Group. Vacuum Technology 2017. Available online: http://www.water.bilfinger.com/applications/ vacuum-technology/ (accessed on 25 January 2017).

62. Panfil, C.; Mirel, I.; Szigyarto, I.; Isacu, M. Technical, economical, social and ecological characteristics of vacuum sewage system. Environ. Eng. Manag. J. 2013, 12, 1017-1022.

63. Terryn, I.C.C.; Lazar, I.; Nedeff, V.; Lazar, G. Conventional vs. vacuum sewerage system in rural areas-An economic and environmental approach. Environ. Eng. Manag. J. 2014, 13, 1847-1859.

64. Elawwad, A.; Ragab, M.; Abdel-Halim, H. Vacuum sewerage system in developing regions and the impact on environmental management. In Proceedings of the 4th International Conference on Environmental Pollution and Remediation Prague, Prague, Czech Republic, 11-13 August 2014.

65. Little, C.J. A comparison of sewer reticulation system design standards gravity, vacuum and small bore sewers. Water SA 2005, 30, 137-144. [CrossRef]

66. United Nations Environment Programme (UNEP). Status Report on the Application of Integrated Approaches to Water Resources Management; United Nations Environment Programme: Nairobi, Kenya, 2012; p. 119.

67. Ma, X.C.; Xue, X.; González-Mejía, A.; Garland, J.; Cashdollar, J. Sustainable water systems for the city of tomorrow-A conceptual framework. Sustainability 2015, 7, 12071-12105. [CrossRef]

68. United States Environmental Protection Agency (US EPA). Response to Congress on Use of Decentralized Wastewater Treatment Systems; EPA-832-R-97-001b; US EPA Office of Water: Washington, DC, USA, 1997.

69. Massoud, M.A.; Tarhini, A.; Nasr, J.A. Decentralized approaches to wastewater treatment and management: Applicability in developing countries. J. Environ. Manag. 2009, 90, 652-659. [CrossRef] [PubMed]

(C) 2017 by the author. Licensee MDPI, Basel, Switzerland. This article is an open access article distributed under the terms and conditions of the Creative Commons Attribution (CC BY) license (http://creativecommons.org/licenses/by/4.0/). 